\title{
RESPON PERTUMBUHAN DAN PRODUKSI TANAMAN KANGKUNG (Ipomoea reptana $P$.) TERHADAP PEMBERIAN PUPUK ORGANIK CAIR GDM DAN DOLOMIT
}

\author{
Wiwik Yunidawati \\ Universitas Amir Hamzah \\ wiwikunham@gmail.com
}

\begin{abstract}
Abstrak
Penelitian ini bertujuan untuk mengetahui pengaruh pemberian pupuk organik cair GDM dan dolomit terhadap pertumbuhan dan produksi tanaman kangkung (Ipomoea reptana P.). Penelitian ini dilaksanakan di Kebun Percobaan Fakultas Pertanian Universitas Amir Hamzah Medan dengan ketinggian tempat $\pm 25 \mathrm{~m}$ di atas permukaan laut dengan topografi datar. Penelitian dilaksanakan mulai bulan April sampai Mei 2020. Penelitian ini menggunakan Rancangan Acak Kelompok (RAK) Faktorial dengan dua faktor, faktor pertama adalah pemberian Pupuk Organik Cair GDM (O) terdiri atas 4 taraf yaitu : $\mathrm{O}_{0}=0 \mathrm{l} / \mathrm{ha}(0 \mathrm{ml} / \mathrm{plot} / \mathrm{l}$ larut $), \mathrm{O}_{1}=20 \mathrm{l} / \mathrm{ha}(2 \mathrm{ml} / \mathrm{plot} / \mathrm{l}$ larut), $\mathrm{O}_{2}=40 \mathrm{l} / \mathrm{ha}(4 \mathrm{ml} / \mathrm{plot} / \mathrm{l}$ larut $), \mathrm{O}_{3}=60 \mathrm{l} / \mathrm{ha}(6 \mathrm{ml} / \mathrm{plot} / \mathrm{l}$ larut $)$. Faktor kedua adalah pemberian Dolomit (D) terdiri atas 3 taraf yaitu : $\mathrm{D}_{0}=0$ ton/ha $(0 \mathrm{~kg} / \mathrm{plot}) / \mathrm{kontrol}, \mathrm{D}_{1}=5$ ton/ha $(0,5 \mathrm{~kg} / \mathrm{plot}), \mathrm{D}_{2}=10$ ton $/ \mathrm{ha}(1,0 \mathrm{~kg} / \mathrm{plot})$. Parameter yang diamati meliputi tinggi tanaman $(\mathrm{cm})$, jumlah daun (helai), produksi per tanaman sampel (gr), produksi per plot $(\mathrm{kg})$. Hasil penelitian menunjukkan bahwa pemberian pupuk organik cair GDM berpengaruh sangat nyata terhadap tinggi tanaman dan jumlah daun pada umur 4 minggu setelah tanam, berpengaruh nyata terhadap produksi per tanaman sampel, serta berpengaruh tidak nyata terhadap produksi per plot. Hasil terbaik diperoleh pada perlakuan $\mathrm{O}_{3}$ yaitu $60 \mathrm{l} / \mathrm{ha}(6 \mathrm{ml} / \mathrm{plot} / \mathrm{l}$ larut $)$. Pemberian Dolomit berpengaruh sangat nyata terhadap tinggi tanaman dan jumlah daun pada umur 4 minggu setelah tanam, serta berpengaruh tidak nyata terhadap produksi per tanaman sampel dan produksi per plot. Hasil terbaik diperoleh pada perlakuan $\mathrm{D}_{2}$ yaitu 10 ton/ha (1,0 kg/plot). Interaksi antara pupuk organik cair GDM dan Dolomit berpengaruh tidak nyata terhadap semua parameter penelitian.
\end{abstract}

Keyword : pupuk organik cair GDM, dolomit, kangkung

Jurnal Insitusi Politeknik Ganesha Medan 


\section{PENDAHULUAN}

Urbanisasi penduduk pedesaan ke daerah perkotaan tidak dapat dihindari karena pesatnya pertumbuhan ekonomi di daerah perkotaan. Meningkatnya jumlah penduduk di daerah perkotaan membawa dampak terhadap peningkatan kebutuhan pangan, khususnya sayuran. Kangkung (Ipomoea reptans P.) adalah sayuran yang sangat populer, karena selain harganya paling murah, juga memiliki banyak peminat karena merupakan sumber vitamin pro vitamin A (Hirmanto, 2009).Usahatani sayuran di pinggiran perkotaan dihadapkan pada masalah sempitnya lahan serta tingginya tuntutan masyarakat terhadap kualitas lingkungan, sehingga dengan demikian penerapan budidaya hemat lahan dengan menitik beratkan pada masukan/input organik perlu dilakukan. Berbagai upaya sudah dilakukan untuk dapat meningkatkan produksi sayuran, namun demikian masih belum dapat mengimbangi permintaan pasar. Keadaan ini dimungkinkan antara lain sebagai akibat peningkatan jumlah penduduk, perbaikan pendapatan dan peningkatan kesadaran gizi masyarakat. Selain itu di kota-kota besar tumbuh permintaan pasar yang menghendaki komoditas sayuran dengan kualitas yang baik (Syarief, 2009). Usaha untuk dapat meningkatkan produktivitas kangkung diantaranya dapat dilakukan dengan pemberian pupuk, baik pupuk organik maupun pupuk anorganik. Pemberian pupuk organik dapat memperbaiki sifat-sifat tanah seperti sifat fisik, kimia dan biologi tanah. Pemberian pupuk organik dapat meningkatkan daya larut unsur $\mathrm{P}, \mathrm{K}, \mathrm{Ca}$ dan $\mathrm{Mg}$, meningkatkan C-organik, kapasitas tukar kation, kapasitas tanah memegang air, menurunkan kejenuhan $\mathrm{Al}$ dan bulk density (BD) tanah (Lingga dan Marsono, 2001). Beberapa macam pupuk organik dengan keunggulan dan kelemahannya masing-masing banyak tersedia di pasaran misalnya POC GDM. Pupuk organik cair GDM merupakan pupuk cair organik serbaguna yang menunjang pertumbuhan dan perkembangan akar tanaman, meningkatkan daya tahan toleransi tanaman terhadap penyakit, dan menghasilkan tanaman yang lebih kuat pada kondisi yang ekstrim. Pupuk organik cair GDM menstimulasi aktivitas mikroba di dalam tanah yang menghasilkan unsur-unsur makro seperti Nitrogen $(\mathrm{N})$, Phospor (P), dan Kalium (K) (Anonim, 2013). Selain pemberian pupuk organik, Sumarno $d k k$ (2001) menyatakan bahwa kangkung sangat membutuhkan unsur N, P, K, dan Ca dalam jumlah yang cukup, dan hal tersebut dapat dipenuhi melalui usaha pemberian kapur. Kapur sebagai bahan penyedia kalsium diambil dari tanah sebagai kation $\mathrm{Ca}+$. Pemberian kapur tidak saja menambah $\mathrm{Ca}$ itu sendiri, namun mengakibatkan pula unsur lain 
menjadi lebih tersedia, baik pada lapisan ginofor maupun pada daerah akar tanaman. Tersedianya $\mathrm{Ca}$ dan unsur lainnya menyebabkan pertumbuhan vegetatif tanaman menjadi lebih baik, sehingga mengakibatkan hasil menjadi lebih tinggi (Sutarto $d k k ., 2005$ ). Pada saat ini sistem pertanian konvensional yang banyak menggunakan input kimiawi buatan dinilai tidak dapat lagi mempertahankan kelestarian lahan dan lingkungan dalam jangka panjang, bahkan kecenderungan yang ada akhir-akhir ini justru terjadi penurunan produktivitas tanaman. Mengingat peran pupuk organik dan pengapuran pada tanah dan tanaman sangat penting, maka disusunlah penelitian untuk mempelajari pengaruh POC GDM dan dolomit terhadap pertumbuhan tanaman kangkung.

\section{METODE PENELITIAN}

Penelitian ini dilaksanakan di Kebun Percobaan Fakultas Pertanian Universitas Amir Hamzah, Medan dengan ketinggian tempat $\pm 25 \mathrm{~m}$ di atas permukaan laut dengan topografi datar. Penelitian dilaksanakan mulai bulan April sampai Mei 2020. Alat-alat yang digunakan dalam penelitian ini adalah cangkul, gembor, meteran, sprayer, kalkulator, timbangan, papan plot dan alat-alat lain yang mendukung dalam pelaksanaan penelitian ini. Bahan-bahan yang digunakan dalam penelitian ini adalah benih kangkung, pupuk kandang ayam, pupuk organik cair GDM, dolomit, air, insektisida bahan aktif Deltametrin $25 \mathrm{~g} / 1$ (Decis 2.5 EC), fungisida bahan aktif Mankozed (Dithane M-45).

Penelitian dilakukan dengan menggunakan Rancangan Acak Kelompok (RAK) Faktorial yang terdiri dari 2 taraf dengan 3 level perlakuan untuk faktor pertama dan 4 level perlakuan untuk faktor kedua, yaitu :

1. Faktor pemberian pupuk organik cair GDM, terdiri dari 4 taraf, yaitu :
$\mathrm{O}_{0} \quad=0 \mathrm{l} / \mathrm{ha}$
(0 ml/plot/l larut) kontrol
$\mathrm{O}_{1}=20 \mathrm{l} / \mathrm{ha}$
( $2 \mathrm{ml} / \mathrm{plot} / \mathrm{l}$ larut)
$\mathrm{O}_{2}=40 \mathrm{l} / \mathrm{ha}$
(4 ml/plot/l larut)
$\mathrm{O}_{3}=60 \mathrm{l} / \mathrm{ha}$
(6 ml/plot/l larut)

2. Faktor pemberian dolomit, terdiri dari 3 taraf, yaitu :
$\mathrm{D}_{0} \quad=0$ ton/ha
(0 kg/plot) kontrol
$\mathrm{D}_{1}=5$ ton $/$ ha
$(0,5 \mathrm{~kg} / \mathrm{plot})$
$\mathrm{D}_{2}=10$ ton/ha
$(1,0 \mathrm{~kg} / \mathrm{plot})$ 
Jumlah kombinasi perlakuan adalah $3 \times 4=12$ perlakuan.

Model linier rancangan acak kelompok (RAK) Faktorial adalah sebagai berikut (Gomez and gomez, 2007) :

$$
\begin{aligned}
\text { Yijk }= & \mu+\alpha \mathrm{i}+\beta \mathrm{j}+\rho \mathrm{k}+(\alpha \beta) \mathrm{ij}+\text { eijk dimana : } \\
\text { Yjik = } & \text { Hasil pengamatan dari faktor pemberian pupuk organik cair GDM } \\
& \text { taraf ke-i dan faktor pemberian dolomit taraf ke- } \mathrm{k}
\end{aligned}
$$

Jika analisis sidik ragam menunjukkan berbeda nyata atau sangat nyata, uji dilanjutkan dengan menggunakan uji BNJ jika KK <10\%, uji BNT jika KK $10 \%$ $20 \%$, dan DMRT jika KK > 20\%.

\section{DISCUSSION}

\section{Tinggi Tanaman (cm)}

Data analisis sidik ragam terhadap peubah amatan tinggi tanaman kangkung pada umur 2, 3 dan 4 MST dapat dilihat pada Lampiran 8, 11, dan 14. Dari hasil analisis sidik ragam menunjukkan bahwa pemberian pupuk organik cair GDM berpengaruh sangat nyata terhadap peubah amatan tinggi tanaman kangkung pada umur 2, 3, dan 4 MST. Pemberian dolomit menunjukkan pengaruh sangat nyata terhadap peubah amatan tinggi tanaman kangkung pada umur 2, 3 dan 4 MST. Interaksi antara kedua perlakuan pemberian pupuk organik cair GDM dan dolomit terhadap tanaman kangkung menunjukkan pengaruh tidak nyata pada umur 2, 3, dan 4 MST pada peubah amatan tinggi tanaman kangkung.

Hasil uji beda rata-rata pengaruh pemberian pupuk organik cair GDM dan dolomit terhadap peubah amatan tinggi tanaman kangkung pada umur 4 MST dapat dilihat pada Tabel 1 di bawah ini : 
Tabel 1. Hasil Uji Beda Rataan Pengaruh Pemberian Pupuk Organik Cair GDM dan Dolomit Terhadap Tinggi Tanaman (cm) Kangkung Umur 4 MST

\begin{tabular}{ccccccc}
\hline \multirow{2}{*}{ Perlakuan D } & \multicolumn{6}{l}{ Perlakuan $\mathrm{O}$} \\
\cline { 2 - 7 } & $\mathrm{O}_{0}$ & $\mathrm{O}_{1}$ & $\mathrm{O}_{2}$ & $\mathrm{O}_{3}$ & Total & Rataan \\
\hline $\mathrm{D}_{0}$ & $37,12 \mathrm{a}$ & $38,38 \mathrm{a}$ & $39,63 \mathrm{a}$ & $38,72 \mathrm{a}$ & 153,85 & $38,46 \mathrm{~b}$ \\
$\mathrm{D}_{1}$ & $39,44 \mathrm{a}$ & $41,23 \mathrm{a}$ & $43,73 \mathrm{a}$ & $45,14 \mathrm{a}$ & 169,54 & $42,39 \mathrm{a}$ \\
$\mathrm{D}_{2}$ & $38,85 \mathrm{a}$ & $42,36 \mathrm{a}$ & $43,77 \mathrm{a}$ & $45,79 \mathrm{a}$ & 170,76 & $42,69 \mathrm{a}$ \\
\hline Total & 115,41 & 121,97 & 127,12 & 129,65 & 494,16 & - \\
\hline Rataan & $38,47 \mathrm{c}$ & $40,66 \mathrm{~b}$ & $42,37 \mathrm{~b}$ & $43,22 \mathrm{a}$ & - & $\mathrm{KK}=3,40 \%$
\end{tabular}

Keterangan : Angka-angka yang diikuti oleh huruf kecil yang tidak sama pada kolom yang sama menunjukkan berbeda nyata menurut uji BNJ pada taraf uji 5\%.

Dari Tabel 1 dapat dilihat bahwa pengaruh pemberian pupuk organik cair GDM terhadap peubah amatan tinggi tanaman kangkung pada umur 4 MST yang paling baik terdapat pada perlakuan $\mathrm{O}_{3}$ dengan pemberian pupuk organik cair GDM sebanyak $6 \mathrm{ml} / \mathrm{plot} / \mathrm{l}$ larut. Tinggi tanaman kangkung yang tertinggi adalah 43,22 cm. Pengamatan tinggi tanaman kangkung yang terendah terdapat pada perlakuan $\mathrm{O}_{0}$ yaitu tanpa pemberian pupuk organik cair GDM (kontrol) pada tanaman kangkung. Tinggi tanaman kangkung yang terendah adalah $38,47 \mathrm{~cm}$. Pemberian pupuk organik cair GDM terhadap peubah amatan tinggi tanaman kangkung pada umur 4 MST dapat dilihat pada grafik dibawah ini : 


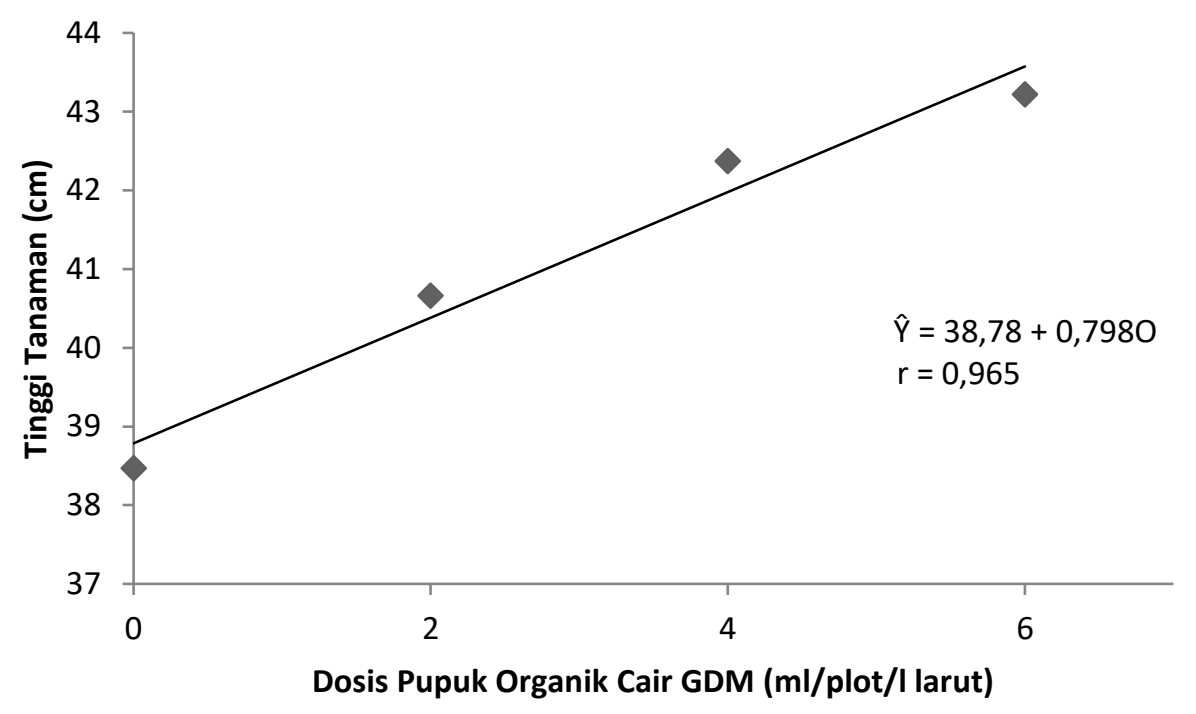

Gambar 1. Pengaruh Pemberian Pupuk Organik Cair GDM Terhadap Peubah Amatan Tinggi Tanaman Kangkung Pada Umur 4 MST.

Dari Tabel 1 juga dapat dilihat bahwa pengaruh pemberian dolomit terhadap peubah amatan tinggi tanaman kangkung pada umur 4 MST yang paling baik terdapat pada perlakuan $\mathrm{D}_{2}$ dengan pemberian dolomit sebanyak $1,0 \mathrm{~kg} / \mathrm{plot}$. Tinggi tanaman kangkung yang tertinggi adalah 42,69 $\mathrm{cm}$. Pengamatan tinggi tanaman kangkung yang terendah terdapat pada perlakuan $\mathrm{D}_{0}$ yaitu tanpa pemberian dolomit (kontrol) pada tanaman kangkung. Tinggi tanaman kangkung yang terendah adalah $38,46 \mathrm{~cm}$. Pemberian dolomit terhadap peubah amatan tinggi tanaman kangkung pada umur 4 MST dapat dilihat pada grafik di bawah ini: 


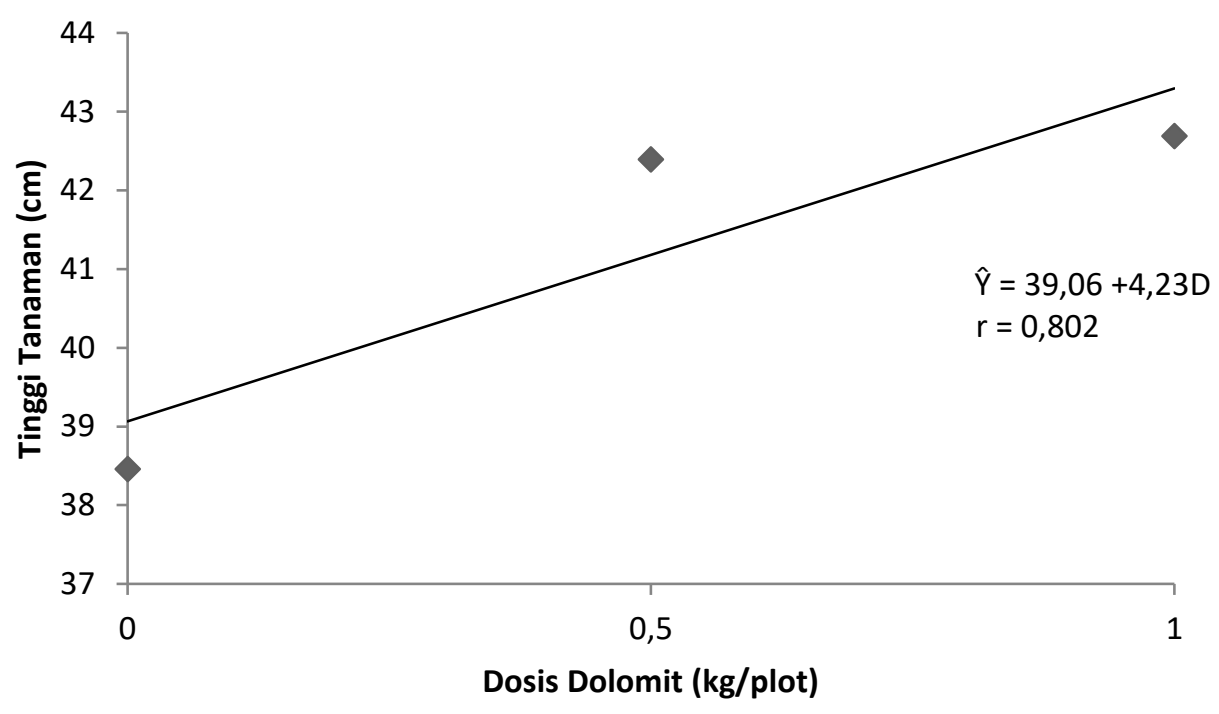

Gambar 2. Pengaruh Pemberian Dolomit Terhadap Peubah Amatan Tinggi Tanaman Kangkung Pada Umur 4 MST.

\section{Jumlah Daun (helai)}

Data analisis sidik ragam terhadap peubah amatan jumlah daun tanaman kangkung pada umur 2, 3 dan 4 MST dapat dilihat pada Lampiran 17, 20, dan 23. Dari hasil analisis sidik ragam menunjukkan bahwa pemberian pupuk organik cair GDM berpengaruh sangat nyata terhadap peubah amatan jumlah daun tanaman kangkung pada umur 2, 3, dan 4 MST. Pemberian dolomit menunjukkan pengaruh sangat nyata terhadap peubah amatan jumlah daun tanaman kangkung pada umur 2, 3 dan 4 MST. Interaksi antara kedua perlakuan pemberian pupuk organik cair GDM dan dolomit terhadap tanaman kangkung menunjukkan pengaruh tidak nyata pada umur 2, dan 3 MST, namun berpengaruh sangat nyata pada umur 4 MST pada peubah amatan jumlah daun tanaman kangkung.

Hasil uji beda rata-rata pengaruh interaksi pemberian pupuk organik cair GDM dan dolomit terhadap peubah amatan jumlah daun tanaman kangkung pada umur 4 MST dapat dilihat pada Tabel 2 berikut ini :

Tabel 2. Hasil Uji Beda Rataan Pengaruh Pemberian Pupuk Organik Cair GDM dan Dolomit Terhadap Jumlah Daun (helai) Tanaman Kangkung Umur 4 MST

Perlakuan D Perlakuan O 


\begin{tabular}{crrrrrrr} 
& $\mathrm{O}_{0}$ & $\mathrm{O}_{1}$ & $\mathrm{O}_{2}$ & $\mathrm{O}_{3}$ & Total & Rataan \\
\cline { 1 - 1 } $\mathrm{D}_{0}$ & $7,93 \mathrm{de}$ & $8,20 \mathrm{c}$ & $8,30 \mathrm{c}$ & $8,23 \mathrm{c}$ & 32,67 & $8,17 \mathrm{~b}$ \\
$\mathrm{D}_{1}$ & $8,10 \mathrm{~d}$ & $8,63 \mathrm{~b}$ & $8,63 \mathrm{~b}$ & $8,80 \mathrm{~b}$ & 34,17 & $8,54 \mathrm{a}$ \\
$\mathrm{D}_{2}$ & $7,83 \mathrm{e}$ & $8,57 \mathrm{bc}$ & $8,43 \mathrm{c}$ & $8,97 \mathrm{a}$ & 33,80 & $8,45 \mathrm{a}$ \\
\hline Total & 23,87 & 25,40 & 25,37 & 26,00 & 100,63 & - \\
\hline Rataan & $7,96 \mathrm{~b}$ & $8,47 \mathrm{a}$ & $8,46 \mathrm{a}$ & $8,67 \mathrm{a}$ & - & $\mathrm{KK}=1,86 \%$
\end{tabular}

Keterangan : Angka-angka yang diikuti oleh huruf kecil yang tidak sama pada kolom yang sama menunjukkan berbeda nyata menurut uji BNJ pada taraf uji $5 \%$.

Dari Tabel 2 dapat dilihat bahwa pengaruh pemberian pupuk organik cair GDM terhadap peubah amatan jumlah daun tanaman kangkung pada umur 4 MST yang paling baik terdapat pada perlakuan $\mathrm{O}_{3}$ dengan pemberian pupuk organik cair GDM sebanyak $6 \mathrm{ml} / \mathrm{plot} / \mathrm{l}$ larut. Jumlah daun tanaman kangkung yang terbanyak adalah 8,67 helai. Pengamatan jumlah daun tanaman kangkung yang terendah terdapat pada perlakuan $\mathrm{O}_{0}$ yaitu tanpa pemberian pupuk organik cair GDM (kontrol) pada tanaman kangkung. Jumlah daun tanaman kangkung yang terendah adalah 7,96 helai.

Pengaruh pemberian dolomit terhadap peubah amatan jumlah daun tanaman kangkung pada umur 4 MST yang paling baik terdapat pada perlakuan $\mathrm{D}_{1}$ dengan pemberian dolomit sebanyak $0,5 \mathrm{~kg} / \mathrm{plot}$. Jumlah daun tanaman kangkung yang terbanyak adalah 8,54 helai. Pengamatan jumlah daun tanaman kangkung yang terendah terdapat pada perlakuan $\mathrm{D}_{0}$ yaitu tanpa pemberian dolomit (kontrol) pada tanaman kangkung. Jumlah daun tanaman kangkung yang terendah adalah 8,17 helai.

Dari Tabel 2 juga dapat dilihat bahwa pengaruh interaksi pemberian pupuk organik cair GDM dan dolomit terhadap peubah amatan jumlah daun tanaman kangkung pada umur 4 MST yang paling baik terdapat pada perlakuan $\mathrm{O}_{3} \mathrm{D}_{2}$ dengan pemberian pupuk organik cair GDM sebanyak $6 \mathrm{ml} / \mathrm{plot} / \mathrm{l}$ larut dan dolomit sebanyak 1,0 kg/plot. Jumlah daun tanaman kangkung yang terbanyak adalah 8,97 helai. Pengamatan jumlah daun tanaman kangkung yang terendah terdapat pada perlakuan $\mathrm{O}_{0} \mathrm{D}_{2}$ yaitu tanpa pemberian pupuk organik cair GDM dan pemberian dolomit sebanyak 1,0 kg/plot. Jumlah daun tanaman kangkung 
yang terendah adalah 7,83 helai. Pengaruh interaksi pemberian pupuk organik cair GDM dan dolomit terhadap peubah amatan jumlah daun tanaman kangkung pada umur 4 MST dapat dilihat pada grafik dibawah ini :
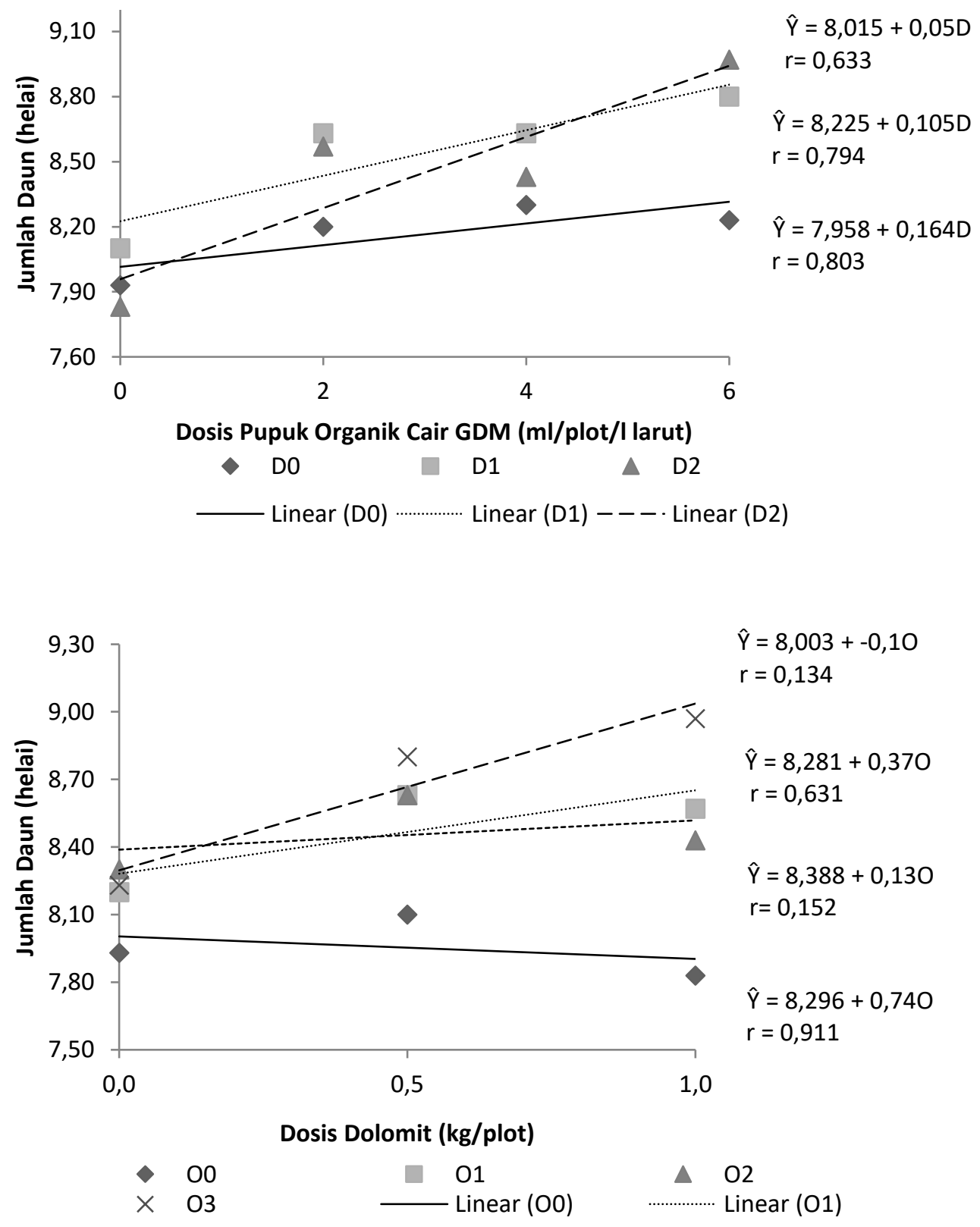

Gambar 3. Interaksi Pemberian Pupuk Organik Cair GDM dan Dolomit Terhadap Peubah Amatan Jumlah Daun Tanaman Kangkung Pada Umur 4 MST 


\section{Produksi Pertanaman Sampel (g)}

Data analisis sidik ragam terhadap peubah amatan produksi pertanaman sampel dapat dilihat pada Lampiran 26. Dari hasil analisis sidik ragam menunjukkan bahwa pemberian pupuk organik cair GDM berpengaruh nyata terhadap peubah amatan produksi pertanaman sampel. Pemberian dolomit menunjukkan pengaruh tidak nyata terhadap peubah amatan produksi pertanaman sampel. Interaksi antara kedua perlakuan pemberian pupuk organik cair GDM dan dolomit terhadap tanaman kangkung menunjukkan pengaruh tidak nyata pada peubah amatan produksi pertanaman sampel.

Hasil uji beda rata-rata pengaruh pemberian pupuk organik cair GDM terhadap peubah amatan produksi pertanaman sampel dapat dilihat pada Tabel 3 berikut ini :

Tabel 3. Hasil Uji Beda Rataan Pengaruh Pemberian Pupuk Organik Cair GDM Terhadap Produksi Pertanaman Sampel (kg)

\begin{tabular}{ccccccc}
\hline \multirow{2}{*}{ Perlakuan D } & \multicolumn{5}{l}{ Perlakuan O } \\
\cline { 2 - 7 } & $\mathrm{O}_{0}$ & $\mathrm{O}_{1}$ & $\mathrm{O}_{2}$ & $\mathrm{O}_{3}$ & Total & Rataan \\
\hline $\mathrm{D}_{0}$ & $21,17 \mathrm{a}$ & $22,17 \mathrm{a}$ & $25,33 \mathrm{a}$ & $24,83 \mathrm{a}$ & 93,50 & $23,38 \mathrm{a}$ \\
$\mathrm{D}_{1}$ & $21,50 \mathrm{a}$ & $26,00 \mathrm{a}$ & $25,83 \mathrm{a}$ & $25,67 \mathrm{a}$ & 99,00 & $24,75 \mathrm{a}$ \\
$\mathrm{D}_{2}$ & $23,83 \mathrm{a}$ & $24,67 \mathrm{a}$ & $24,83 \mathrm{a}$ & $26,83 \mathrm{a}$ & 100,17 & $25,04 \mathrm{a}$ \\
\hline Total & 66,50 & 72,83 & 76,00 & 77,33 & 292,67 & - \\
\hline Rataan & $22,17 \mathrm{c}$ & $24,28 \mathrm{~b}$ & 25,33 a & $25,78 \mathrm{a}$ & - & $\mathrm{KK}=9,99 \%$ \\
\hline Keterangan : Angka-angka yang dikuti oleh huruf kecil yang tidak sama pada kolom yang \\
sama menunjukkan berbeda nyata menurut uji BNJ pada taraf uji 5\%.
\end{tabular}

Dari Tabel 3 dapat dilihat bahwa pengaruh pemberian pupuk organik cair GDM terhadap peubah amatan produksi pertanaman sampel yang paling baik terdapat pada perlakuan $\mathrm{O}_{3}$ dengan pemberian pupuk organik cair GDM sebanyak $6 \mathrm{ml} / \mathrm{plot} / \mathrm{l}$ larut. produksi pertanaman sampel yang tertinggi adalah 25,78 g. Pengamatan produksi pertanaman sampel yang terendah terdapat pada perlakuan $\mathrm{O}_{0}$ yaitu tanpa pemberian pupuk organik cair GDM (kontrol) pada tanaman kangkung. produksi pertanaman sampel yang terendah adalah 22,17 g. Pemberian 
pupuk organik cair GDM terhadap peubah amatan produksi pertanaman sampel dapat dilihat pada grafik dibawah ini :

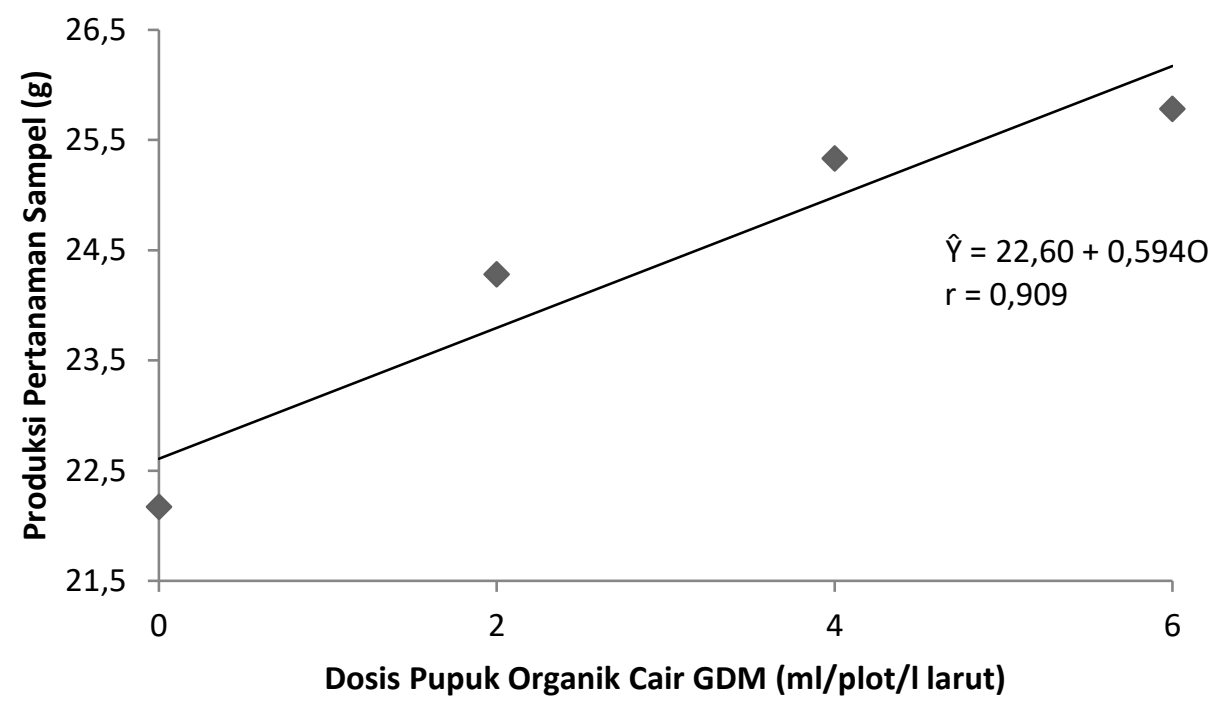

Gambar 4. Pengaruh Pemberian Pupuk Organik Cair GDM Terhadap Peubah Amatan Produksi Pertanaman Sampel.

\section{Produksi Per Plot (kg)}

Hasil pengamatan terhadap peubah amatan produksi per plot pada tanaman kangkung dapat dilihat pada Lampiran 29 yang menunjukkan bahwa pemberian pupuk organik cair GDM berpengaruh tidak nyata terhadap peubah amatan produksi per plot. Begitu juga dengan pemberian dolomit yang menunjukkan pengaruh tidak nyata pada tanaman kangkung. Interaksi antara pemberian pupuk organik cair GDM dan dolomit juga memperlihatkan pengaruh tidak nyata terhadap peubah amatan produksi per plot pada tanaman kangkung. Data rataan pengamatan peubah amatan produksi per plot pada tanaman kangkung terhadap pengaruh pemberian pupuk organik cair GDM dan dolomit dapat dilihat pada Tabel 4 dibawah ini :

Tabel 4. Data Rataan Peubah Amatan Produksi Per Plot (kg) 


\begin{tabular}{ccccccc}
\hline \multirow{2}{*}{ Perlakuan D } & \multicolumn{7}{l}{ Perlakuan $\mathrm{O}$} \\
\cline { 2 - 7 } & $\mathrm{O}_{0}$ & $\mathrm{O}_{1}$ & $\mathrm{O}_{2}$ & $\mathrm{O}_{3}$ & Total & Rataan \\
\hline $\mathrm{D}_{0}$ & $2,27 \mathrm{a}$ & $2,47 \mathrm{a}$ & $2,67 \mathrm{a}$ & $2,77 \mathrm{a}$ & 10,17 & $2,54 \mathrm{a}$ \\
$\mathrm{D}_{1}$ & $2,23 \mathrm{a}$ & $2,43 \mathrm{a}$ & $2,63 \mathrm{a}$ & $2,30 \mathrm{a}$ & 9,60 & $2,40 \mathrm{a}$ \\
$\mathrm{D}_{2}$ & $2,73 \mathrm{a}$ & $2,43 \mathrm{a}$ & $2,60 \mathrm{a}$ & $2,60 \mathrm{a}$ & 10,37 & $2,59 \mathrm{a}$ \\
\hline Total & 7,23 & 7,33 & 7,90 & 7,67 & 30,13 & - \\
\hline Rataan & $2,41 \mathrm{a}$ & $2,44 \mathrm{a}$ & $2,63 \mathrm{a}$ & $2,56 \mathrm{a}$ & - & $\mathrm{KK}=10,92 \%$ \\
\hline Keterangan : Angka-angka yang diikuti oleh huruf kecil yang sama pada kolom yang sama \\
menunjukkan berbeda tidak nyata menurut uji BNT pada taraf uji 5\%.
\end{tabular}

Dari Tabel 4 dapat dilihat bahwa pengaruh pemberian pupuk organik cair GDM, dolomit, dan interaksinya terhadap peubah amatan produksi per plot tanaman kangkung menunjukkan pengaruh tidak nyata yang ditunjukkan dari notasi pada angka-angka di dalam tabel.

\section{PEMBAHASAN}

1. Respon Pertumbuhan dan Produksi Tanaman Kangkung Terhadap Pemberian Pupuk Organik Cair GDM

Dalam penelitian ini, salah satu perlakuan pupuk untuk tanaman kangkung menggunakan pupuk organik cair GDM yang merupakan pupuk organik. Pupuk organik sebenarnya telah lama digunakan oleh nenek moyang kita jauh sebelum manusia mengenal pupuk kimia. Nenek moyang kita menggunakan sisa-sisa makanan mereka yang berupa sayur-sayuran, tulang, ikan dan segala sesuatu yang merupakan sisa makanan mereka. Mereka menimbun hal-hal tersebut di dalam tanah yang nantinya tempat tersebut mereka gunakan tempat itu untuk bercocok tanam. Pada mulanya mereka tanpa sengaja melakukan hal ini, akan tetapi mereka mengamati dengan melakukan hal tersebut, tanaman yang ditanam menjadi lebih subur. Oleh karena itu mereka terus melakukan hal tersebut dengan maksud tanaman dapat menjadi lebih subur. Menurut Leiwakabessy dan Sutandi (2004) pupuk merupakan suatu bahan yang diberikan pada tanaman baik secara langsung 
maupun tidak langsung untuk mendorong pertumbuhan tanaman, meningkatkan produksi atau memperbaiki kualitasnya sebagai akibat perbaikan nutrisi tanaman

Berdasarkan hasil penelitian diperoleh bahwa pemberian pupuk organik cair GDM pada tanaman kangkung menunjukkan pengaruh yang sangat nyata pada peubah amatan tinggi tanaman dan jumlah daun pada umur 2, 3, dan 4 MST serta produksi pertanaman sampel menunjukkan pengaruh yang nyata. Pemberian pupuk urea cair GDM lebih berpengaruh pada tanaman kangkung pada fase vegetatif karena pupuk organik cair GDM merupakan pupuk cair organik serbaguna yang menunjang pertumbuhan dan perkembangan akar tanaman, meningkatkan daya tahan toleransi tanaman terhadap penyakit, dan menghasilkan tanaman yang lebih kuat pada kondisi yang ekstrim. Menurut Anonim (2013) pupuk organik cair GDM menstimulasi aktivitas mikroba di dalam tanah yang menghasilkan unsur-unsur makro seperti Nitrogen (N), Phospor (P), dan Kalium (K) (Anonim, 2013). Selain itu pupuk organik cair GDM merupakan pupuk organik cair yang di hasilkan dari bahan-bahan organik dan bakteri yang diperlukan oleh tanaman (Satar, 2014).

Pemberian pupuk organik cair GDM pada tanaman kangkung dapat menambah tinggi tanaman dan jumlah daun setiap minggu pengamatan. Penambahan tinggi dapat terlihat pada pemberian pupuk organik cair GDM di perlakuan $\mathrm{O}_{3}$ yaitu sebanyak $6 \mathrm{ml} / \mathrm{plot} / \mathrm{l}$ larut. Dosis pemberian pupuk organik cair GDM ini sesuai dengan dosis yang dianjurkan untuk tanaman sayur-sayuran. Menurut Anonim (a) (2013) untuk tanaman sayur-sayuran (bayam, sawi, selada, kangkung, seledri, brokoli, bunga kol, kubis : Dosis : 40-60 Ltr GDM/Ha. Selain itu beberapa fakta penggunaan pupuk organik cair GDM di lapangan pada beberapa tanaman baik tanaman pangan, hortikultura atau perkebunan pemberian pupuk cair GDM pada tanaman kangkung menghasilkan daun yang menjadi lebih lebar, dan tunas/semi tumbuh lebih cepat (Satar, 2014).

\section{Respon Pertumbuhan dan Produksi Tanaman Kangkung Terhadap Pemberian Dolomit}

Dalam penelitian ini lokasi penanaman tanaman kangkung berada di Desa Sei Dadap dengan $\mathrm{pH}$ tanah 5,5. $\mathrm{pH}$ tanah pada lokasi penelitian belum sesuai dengan $\mathrm{pH}$ tanah untuk budidaya tanaman kangkung. Oleh karena itu perlu dilakukan pemberian dolomit agar $\mathrm{pH}$ tanah sesuai dengan $\mathrm{pH}$ untuk budidaya tanaman kangkung. Menurut Salikin (2000) Kondisi kimia tanah baik (cocok) untuk tanaman kangkung adalah tanah yang memiliki derajat keasaman tanah $(\mathrm{pH}$ tanah) berkisar 6-7 (netral). Pada $\mathrm{pH}$ tanah yang rendah akan terjadi gangguan penyerapan zat hara oleh tanaman sehingga secara menyeluruh tanaman akan terganggu pertumbuhannya. Jika pada tanah masam kangkung sukar tumbuh, maka diperlukan penambahan kapur untuk menetralkanya. Menurut 
Hardjowigeno (2002) kapur adalah bahan yang mengandung unsur Ca yang dapat meningkatkan $\mathrm{pH}$ tanah. Pemberian kapur dapat meningkatkan ketersediaan unsur $\mathrm{P}$ dan Mo. Pengapuran dapat meningkatkan $\mathrm{pH}$ tanah, sehingga pemberian kapur pada tanah masam akan merangsang pembentukan struktur remah, mempengaruhi pelapukan bahan organik, dan pembentukan humus.

Berdasarkan hasil penelitian diperoleh bahwa pemberian dolomit pada tanaman kangkung lebih berpengaruh pada fase vegetatif dimana peubah amatan tinggi tanaman dan jumlah daun menunjukkan pengaruh yang sangat nyata, tetapi pada fase generatif dimana peubah amatan pada produksi pertanaman sampel dan per plot menunjukkan pengaruh tidak nyata. Dengan pemberian dolomit pada tanaman kangkung selain dapat menaikkan $\mathrm{pH}$ tanah juga tersedianya unsur hara N, P, dan S yang dibutuhkan oleh tanaman kangkung pada fase vegetatif. Menurut Soepardi (2003) menyatakan bahwa pengapuran menetralkan senyawa-senyawa beracun dan menekan penyakit tanaman. Aminisasi, amonifikasi, dan oksidasi belerang nyata dipercepat oleh meningkatnya $\mathrm{pH}$ yang diakibatkan oleh pengapuran. Dengan meningkatnya $\mathrm{pH}$ tanah, maka akan menjadikan tersedianya unsur $\mathrm{N}$, P, dan S, serta unsur mikro bagi tanaman. Pemberian dolomit dapat memperbaiki $\mathrm{pH}$ tanah sekaligus dapat mencukupi kebutuhan unsur hara makro $\mathrm{K}$ dan $\mathrm{Mg}$ bagi tanaman serta dapat menjaga ketersediaan sebagian besar hara mikro bagi tanaman. Penggunaan dolomit sangat berperan mendorong perkembangan akar, memperkuat ketegakkan batang tanaman, Mg-nya merupakan bagian esensial klorofil sehingga tercipta hijau daun kilap bercahaya yang semakin menyempurnakan fotosintesis, mengatur serapan hara lainnya, pembawa $\mathrm{P}$ beredar dalam tubuh tanaman, pembentuk minyak, lemak dan pati serta mendorong perbanyakan produk bijian (Anonim (d), 2013).

\section{Respon Pertumbuhan dan Produksi Tanaman Kangkung Terhadap Interaksi Pemberian Pupuk Organik Cair GDM dan Dolomit}

Dari hasil pengamatan dan pengujian data secara statistik menunjukkan bahwa pengaruh interaksi antara pemberian pupuk urea dan pemberian pupuk surplus terhadap tanaman bayam merah menunjukkan pengaruh nyata pada peubah amatan diameter batang. Diameter batang tanaman bayam merah yang terbesar terdapat pada perlakuan $\mathrm{U}_{2} \mathrm{~S}_{3}$ yaitu $2,82 \mathrm{~mm}$. Hal ini menunjukkan bahwa tanaman bayam merah membutuhkan pupuk urea dan pupuk surplus pada dosis yang tinggi pada fase vegetatif. Hal ini disebabkan karna pada pupuk urea mengandung unsur nitrogen yang dibutuhkan oleh tanaman bayam merah, selain itu pada pupuk surplus juga mengandung unsur hara makro dan mikro yang lengkap. Unsur Makro N 10.39\%, $\mathrm{P}_{2} \mathrm{O}_{5}$ 13,95\%, $\mathrm{K}_{2} \mathrm{O}$ 13,56\% dan Unsur Mikro Ca 0,01\%, Mn 293ppm, Mg 3,62\%, Cu 60ppm, Na 0,07\%, Zn 54ppm, Fe 0,41\%, 
dan S 8,05\% (PT. Samudera surplus, 2010). Selain itu pupuk urea merupakan pupuk yang mengandung nitrogen paling tinggi $(46 \%)$ diantara semua pupuk padat (Anonim, 2010).

\section{KESIMPULAN}

1. Pemberian pupuk organik cair GDM berpengaruh sangat nyata terhadap tinggi tanaman dan jumlah daun pada umur 4 minggu setelah tanam, berpengaruh nyata terhadap produksi per tanaman sampel, serta berpengaruh tidak nyata terhadap produksi per plot. Hasil terbaik diperoleh pada perlakuan $\mathrm{O}_{3}$ yaitu 60 1/ha (6 ml/plot/l larut).

2. Pemberian Dolomit berpengaruh sangat nyata terhadap tinggi tanaman dan jumlah daun pada umur 4 minggu setelah tanam, serta berpengaruh tidak nyata terhadap produksi per tanaman sampel dan produksi per plot. Hasil terbaik diperoleh pada perlakuan $\mathrm{D}_{2}$ yaitu 10 ton/ha $(1,0 \mathrm{~kg} / \mathrm{plot})$.

3. Interaksi antara pupuk organik cair GDM dan Dolomit berpengaruh tidak nyata terhadap semua parameter penelitian.

\section{REFERENCES}

Anonim (a). 2013. GDM. http://gdmorganic.com/bakteri-gdm/ Diakses tanggal 24 Maret 2020; 20.47 WIB.

(b) 2013. Bakteri GDM. http://pupukgdm.blogspot.com/2013/04/gdm.html. Diakses tanggal 24 Maret 2020; 23.24 WIB

(c) 2013. Pusat Penjualan Produk-produk Agribisnis Indonesia. http://www.tokoagro.com. Diakses tanggal 22 Maret 2020; 08.38 WIB.

(d) 2013. Persiapan Budidaya Cabai dengan Memilih http://kayadenganbertani.blogspot.com, diakses 8 September 2020.

Hardjowigeno, S. 2002. Ilmu Tanah. PT. Mediatama Sarana Perkasa. Jakarta. 233 hal.

Haryoto. 2009. Bertanam Kangkung Raksasa di Pekarangan. Kanisius. Yogyakarta.

Hirmanto,S. 2009. Cara Menanam Kangkung Yang Baik dan Benar. Obat Pertanian. Com.

Leiwakabessy, F. M. dan A. Sutandi. 2004. Pupuk dan Pemupukan. Departemen Tanah. Fakultas Pertanian. Institut Pertanian Bogor. Bogor. 208 hal. 
Lingga dan Marsono. 2001. Petunjuk Penggunaan Pupuk. Penebar Swadaya. Jakarta.

Master, W. 2009. Manfaat Dolomit Untuk Padi dan Palawija. www.dolomitsuper.com, Diakses 8 September 2020.

Novel, A. 2013. Informasi Tentang Dolomit. magetan02.com/berita-131-informasitentang-dolomit.html, Diakses 8 September 2020.

Pracaya. 2004. Bertanam Sayuran Organik di Kebun, Pot, Polybag. Penebar Swadaya. Jakarta

Rosmarkam, A. F. 2002. Ilmu Kesuburan Tanah. Kanisius, Yogyakarta.

Sabila, P. 2013. Makalah. Pengaruh Pemberian Air Kelapa dan Air Vetsin Terhadap Pertumbuhan Tanaman Kangkung Darat. Unimed. http://putrisabila13.blogspot.com/2013/10/makalah 6517.html. Diakses tanggal 24 Maret 2020; 20.18 WIB

Salikin, Karwan A, 2000. Sistem Pertanian Berkelanjutan. Kaniusius. Jakarta

Salisbury, FB., Ross, CW. 2005. Fisiologi Tumbuhan. ITB. Bandung.

Satar, R. 2014. Pupuk Organik Cair GDM. http://ramadisatar.blogspot.com/2014/01/pupuk-organik-cair-gdm.html.

Diakses tanggal 24 Maret 2020; 23.20 WIB.

Siagian, P. 2011. Laporan Budidaya Hortikultura Kangkung. Program Study Agroekoteknologi. Fakultas Pertanian. Universitas Jambi. http://anakpintarunja.blogspot.com/2012/06/laporan-budidaya-hortikulturakangkung.html. Diakses tanggal 24 Maret 2020; 19.47 WIB

Soepardi, G. 2003. Sifat dan Ciri Tanah. Jurusan Tanah. Fakultas Pertanian IPB. Bogor.

Sofiari, E. 2009. Karakteristik Kangkung Varietas Sutera Berdasarkan Panduan Pengujian Individual. Buletin Plasma Nutfah. Balai Penelitian Tanaman Sayuran Lembang. Bandung.

Steenis, V. 2005. Flora Untuk Sekolah di Indonesia. Pradnya Paramitha. Jakarta

Sumarno, S.Hartati dan H. Widjianto. 2001. Kajian Macam Pupuk Organik dan Dosis Pupuk P terhadap Hasil Kacang Tanah (Arachis hypogaea, L.) di Tanah Entisol. Sains Tanah. 1(1): 1-6. 
Sutarto, V, S. Hutami, dan B.Soeherdy. 2005. Pengapuran dan Pemupukan Molibdenum, Magnesium, dan Sulfur pada Kacang Tanah. Dalam Seminar Hasil Penelitian Tanaman Pangan volume 1 Palawija. Badan Penelitian dan Pengembangan Pertanian, Pusat Penelitian dan Pengembangan Tanaman Pangan. Bogor. 227 : 146-155.

Syarif, E. 2009. Leaflet. Budidaya Kangkung Darat Semi Organik. BPTP-Jambi. Jambi. 